\title{
岸本祐一郎 学位論文審査要旨
}

$\begin{array}{ccccc}\text { 主查 } & \text { 山 } & \text { 一 } & \text { 博 } \\ \text { 副主查 } & \text { 稲 } & \text { 垣 } & \text { 喜 } & \text { 三 } \\ \text { 同 } & \text { 西 } & \text { 村 } & \text { 元 } & \text { 延 }\end{array}$

\section{主論文}

Development of a novel drive mode to prevent aortic insufficiency during continuous-flow LVAD support by synchronizing rotational speed with heartbeat

(大動脈弁逆流の予防を目的とした定常流左室補助人工心臓における心拍同期回転数制御 を用いた新規駆動法の開発）

(著者：岸本祐一郎、武輪能明、荒川衛、梅木昭秀、安藤政彦、西村隆、藤井豊、 水野敏秀、西村元延、巽英介）

平成25年 Journal of Artificial Organs 掲載予定

\section{参考論文}

1. 胸部解離性大動脈瘤と両側総腸骨動脈閉塞の合併に対しステントグラフトを用いたハ イブリッド治療を施行した1治験例

(著者 : 岸本祐一郎、佐伯宗弘、中村嘉伸、藤原義和、白谷卓、大野原岳史、大月優貴、 岸本諭、西村元延)

平成24年 日本心臓血管外科学会雑誌 41 巻 323 頁 326頁 


\section{学 位 論 文 要 旨}

Development of a novel drive mode to prevent aortic insufficiency during continuous-flow LVAD support by synchronizing rotational speed with heartbeat （大動脈弁逆流の予防を目的とした定常流左室補助人工心臓における心拍同期回転数制御 を用いた新規駆動法の開発）

左室補助人工心臓（Left Ventricular Assist Device：LVAD）は、拍動を発生しない、 いわゆる定常流LVADの臨床応用により飛躍的に長期補助成績が改善した。しかしながら、 LVAD治療の長期化に伴い、大動脈弁逆流（Aortic Insufficiency：AI）の発生が問題とな っている。重症のAIでは、有効ポンプ拍出量が著しく減少することにより、臓器不全をき たす可能性があり、実際にLVAD装着後にAIを発症した患者は、予後不良であることが報告 されている。AIの主要因として、LVAD補助による大動脈弁開口運動の減少があると考えら れており、その対策として、回転数を一定時間低下させる駆動法であるIntermittent Low Speed (ILS) が実用化されている。しかしながら、ILSは補助流量の低下などの問題がある。 そこで本研究では、AI予防を目的として、自己心拍に同期して回転数を変動させるDelayed Copulseモードを新たに開発した。これは収縮期早期に回転数を低下させ、大動脈弁が開口 した直後より回転数を上昇させることで、補助流量低下を最小限にとどめつつ大動脈弁を 開口させることを目的とした駆動法であり、長期の定常流LVAD補助におけるAIの予防に有 用な可能性がある（Intermittent Delayed Copulseモード；IDCOモード）。本研究では、 このIDCOモードについて、ILSモードと比較し、その有用性を流量と大動脈弁開口面積など により評価した。

\section{方 法}

正常心モデルとして成ヤギ7頭（体重52.6 6 4.1 kg）、急性心不全モデルとして成ヤギ 7 頭（体重52.3 3 土 $4.9 \mathrm{~kg}$ ）を左開胸し、EVAHEART（サンメディカル社）を装着した。急性 心不全モデルは、経カテーテル的に冠動脈前下行枝へ75 $\mu$ mマイクロスフィア $(3.1 \pm 0.3$ 万個； 600 / kg）を動注し作成した。条件として、定常回転駆動（100\%バイパス）から間 歇的（80拍中10拍）にDelayed Copulseモード（90\%バイパス）に切り替わるIDC0モード、 定常回転駆動（100\%バイパス）から間歇的（80拍中10拍）に1200 rpmに回転数を下げるILS モードの2条件を設定し、総流量（補助循環流量 + 自己心拍出量）、大動脈弁最大開口面 
積、脈圧を比較した。

\section{結 果}

正常心モデルにおいて、定常回転駆動（平均総流量 $3.17 \pm 0.60 \mathrm{~L} / \mathrm{min}$ ）から各駆動モ 一ド切り替え後の平均総流量はIDC0 / ILS: $3.04 \pm 0.65 / 2.21 \pm 0.75 \mathrm{~L} / \mathrm{min}(\mathrm{p}<0.05)$ であり、また定常回転駆動（最大開口面積 $0.34 \pm 0.59 \mathrm{~cm}^{2}$ ）から各駆動モード切り替え 後の大動脈弁最大開口面積はIDCO / ILS : $2.46 \pm 0.16$ / $2.31 \pm 0.18 \mathrm{~cm}^{2}$ であった。脈 圧は、定常回転駆動（19.6 土7.2 mmHg）から各駆動モード切り替え後、IDCO / ILS : 28.3 $\pm 6.0 / 36.3 \pm 5.8 \mathrm{mmHg}$ であった。急性心不全モデルにおいて、定常回転駆動（平均総 流量 $2.04 \pm 0.62 \mathrm{~L} / \mathrm{min}$ ）から各駆動モード切り替え後の平均総流量はIDCO / ILS : 1.97 $\pm 0.59 / 1.24 \pm 0.31 \mathrm{~L} / \mathrm{min}(\mathrm{p}<0.01)$ であり、また定常回転駆動（最大開口面積 0.06 $\left.\pm 0.15 \mathrm{~cm}^{2}\right)$ から各駆動モード切り替え後の大動脈弁最大開口面積は、IDCO / ILS : 2. 17 $\pm 0.27 / 1.19 \pm 0.69 \mathrm{~cm}^{2}(\mathrm{p}<0.05)$ であった。脈圧は、定常回転駆動 $(17.2 \pm 8.3 \mathrm{mmHg})$ から各駆動モード切り替え後、IDCO / ILS : 29.3 \pm 8.0／ $29.6 \pm 4.7$ mmHgであった。

\section{考 察}

長期の定常流LVAD補助によるAI発生の主要因は、大動脈弁の持続的な閉鎖と脈圧減少に 伴う持続的な大動脈基部圧の上昇であると推察されており、これらが相互に関わることで 大動脈弁交連部の癒合、大動脈基部の拡大をきたし、AIが進行すると考えられている。本 研究結果において、ILSモードは大動脈弁の開口と脈圧の改善を認めるものの、総流量は有 意に低下し、これは正常心モデルより急性心不全モデルにてより顕著であった。一方、 Delayed Copulseモードは、正常心モデルのみならず、急性心不全モデルにおいても総流量 低下を最小限にとどめつつ、大動脈弁の開口と脈圧を改善させることが可能であり、AI予 防の観点から、定常流LVADの長期装着が必要な患者において有用な駆動法であると考えら れた。

\section{結 論}

Delayed Copulseモードは、総流量低下を最小限にとどめつつ大動脈弁の開口と脈圧を改 善させることが可能であり、定常流LVADによる長期循環補助時のAI発生に有用である可能 性が示唆された。 


\section{審 査 結 果 の 要 旨}

補助人工心臓は、拍動を発生しない、いわゆる定常流補助人工心藏の臨床応用により、 飛躍的に長期補助成績が改善した。しかしながら、循環補助の長期化に伴い、大動脈弁逆 流の発生などの新たな合併症が問題となってきている。大動脈弁逆流発生の主たる原因は、 持続的に大動脈弁が閉鎖してしまうことによる弁の癒着変形であると考えられている。そ のため、間欠的に補助流量を下げることによって、大動脈弁の開口を促寸駆動方法も用い られているが、この場合、補助流量が低下してしまうことが問題である。今回の研究では、 定常流補助人工心臓の回転数を自己心拍に同期させて変動させることにより、補助流量を 低下させることなく、大動脈弁の開口が得られる方法を開発した。本研究の成果は、定常 流補助人工心臟の長期成績のさらなる向上につながる可能性がある興味深い研究であり、 明らかに学術の水準を高めたものと認める。 